\title{
Telomeric DNA in Normal and Leukemic Blood Cells
}

\author{
Osamu Yamada, Kazuo Oshimi, Toshiko Motoji, and Hideaki Mizoguchi \\ Department of Hematology, Tokyo Women's Medical College, Tokyo 162, Japan
}

\begin{abstract}
We studied telomeric DNA in leukemic cells as well as in normal $\mathbf{T}$ cells, B cells, monocytes, polymorphonuclear leukocytes, and bone marrow hematopoietic progenitor cells. No marked differences were observed in the sizes of the telomeric repeats in the various populations of normal blood cells obtained from donors in their twenties to sixties, and the telomere length ranged between 8.5 and $9.0 \mathrm{~kb}$. The leukemic cells of 12 patients with acute leukemia (seven with myeloid and five with lymphoid leukemia) showed a variable reduction in the length of telomeric DNA, ranging from 2.7 to $6.4 \mathrm{~kb}$. The average telomere length was 4.8 and $4.7 \mathrm{~kb}$ in myeloid and lymphoid leukemia, respectively, while the telomere length in peripheral blood mononuclear cells obtained from the same patients during complete remission was 8.5 and $7.9 \mathrm{~kb}$, respectively. When the same Southern blots were hybridized with Alu or alphoid sequences, no marked changes in the sizes of the repetitive DNA sequences were observed, indicating that the DNA abnormality in the leukemic cells was specific to the telomere region. Investigation of telomeric DNA changes may be helpful in determining the biological properties of leukemic cells. (J. Clin. Invest. 1995. 95:1117-1123.) Key words: telomeric DNA • myeloid leukemia - lymphocytic leukemia • hematopoietic stem cells $\cdot$ hematologic disease
\end{abstract}

\section{Introduction}

Telomeres are the physical ends of eukaryotic chromosomes (1). The concept of the telomere is derived from the work of Muller and Herskowitz (2) and that of McClintock (3), which was carried out during the 1930s and 1940s. The telomeric DNA sequence is highly conserved in all well-characterized eukaryotic nuclear chromosomes, and is quite different from the termini of linear viral, extranuclear plasmid, or mitochondrial DNA (4).

Telomeres are thought to have at least three functions. (a) They protect the ends of double-stranded DNA from degradation, fusion, and recombination (3). (b) Since telomeres are located at the periphery of the nucleus, they may have a role

Address correspondence to Dr. Osamu Yamada, Department of Hematology, Tokyo Women's Medical College, 8-1 Kawada-cho, Shinjukuku, Tokyo 162, Japan. Phone: 03-3353-8111, ext. 31543; FAX: 033353-6793.

Received for publication 27 July 1994 and in revised form 17 October 1994.

J. Clin. Invest.

(C) The American Society for Clinical Investigation, Inc.

0021-9738/95/03/1117/07 \$2.00

Volume 95, March 1995, 1117-1123 in attaching the ends of chromosomes to the nuclear membrane (5). (c) Telomeres may provide a solution to the end-replication problem (6) since all known polymerases require a primer and synthesize DNA in the $5^{\prime}$ to $3^{\prime}$ direction, so the $3^{\prime}$ end of linear DNA poses a theoretical problem to the replication machinery.

Human telomeric DNA consists of $2-15 \mathrm{~kb}$ of the tandemly repeated sequence (TTAGGG) $\mathrm{n}$, which is oriented in the $5^{\prime}-$ $3^{\prime}$ direction towards the end of the chromosome. The high degree of evolutionary conservation of this repetitive DNA sequence implies that it is essential to cellular function (7). The broken ends of chromosomes are unstable and can fuse end-toend, leading to dicentric ring forms (8). It has been suggested that telomeric fusion may be involved in the development of the chromosome rearrangements which are frequently observed in human neoplasia. Although two types of leukemia with chromosomal telomeric associations have been reported $(9,10)$, descriptions of telomeric DNA changes have only been provided for Wilms' tumor (11), colorectal carcinoma (12), endometrial adenocarcinoma (13), and ovarian carcinoma (14). We recently found that prominent DNA changes were present in two leukemic cell lines (15). Accordingly, the present study was performed to investigate whether or not telomeric DNA loss or reduction occurs in human hematological malignancies. We also compared DNA changes with those occurring in the normal counterparts of the leukemic cells.

\section{Methods}

Cells. After obtaining informed consent, we collected peripheral blood mononuclear cells (PBMC) from 12 leukemia patients. These cells were isolated by Ficoll-Conray density gradient centrifugation both before treatment and after hematological remission. In the blood samples obtained before treatment, over $66 \%$ of the white blood cells were leukemic cells.

Isolation of normal polymorphonuclear leukocytes, monocytes, $T$ cells, and B cells. Heparinized blood from five consenting healthy volunteers aged in their twenties to sixties was carefully layered onto MonoPoly Resolving Medium (ICN Biomedicals Ltd., Irvine, CA) and centrifuged at $1,000 \mathrm{~g}$ for $30 \mathrm{~min}$. This resulted in the separation of mononuclear cells into the top band and polymorphonuclear leukocytes into a second band (16). The polymorphonuclear leukocytes were collected, washed, and resuspended in RPMI-1640 medium containing $10 \%$ fetal calf serum (RPMI-10\%). These leukocytes were of at least $98 \%$ purity as judged by May-Grünwald-Giemsa staining. The recovered mononuclear cells were washed and then incubated at $2 \times 10^{6} / \mathrm{ml}$ for $2 \mathrm{~h}$ at $37^{\circ} \mathrm{C}$ in Petri dishes containing RPMI-10\%. Monolayers were washed six times with RPMI-10\% to remove nonadherent cells and this fraction was later used for lymphocyte separation. The adherent cells were gently scraped off with a rubber policeman and incubated at $5 \times 10^{6} / \mathrm{ml}$ for $45 \mathrm{~min}$ at $37^{\circ} \mathrm{C}$ in a test tube containing RPMI- $10 \%$ with $0.4 \mathrm{mg} / \mathrm{ml}$ carbonyl iron (Sigma Chemical Co., St. Louis, MO). Cells ingesting or adhering to the iron particles were collected with a strong magnet (MPC-6; Dynal, Skoyen, Norway). This procedure provided a monocyte-enriched population which was judged to be $95 \%$ pure by esterase staining (17) and $90 \%$ viable by trypan blue staining. Nonadherent cells 
were allowed to form rosettes for $1 \mathrm{~h}$ at $4^{\circ} \mathrm{C}$ with neuraminidase-treated sheep erythrocytes, and the rosetting $\mathrm{T}$ cells and natural killer cells were then separated from the other mononuclear cells by pelleting through a Ficoll-Conray gradient. The sheep erythrocytes were subsequently lysed with $0.17 \mathrm{M} \mathrm{NH}_{4} \mathrm{Cl}$ for $10 \mathrm{~min}$ at $4^{\circ} \mathrm{C}$, followed by the addition of RPMI-10\%, and a clean pellet of enriched $\mathrm{T}$ cells and natural killer cells was thus obtained. A B cell-enriched fraction was obtained by collecting the nonrosetting cells during this procedure. The $\mathrm{T}$ and $\mathrm{B}$ cell fractions were subsequently suspended at $5 \times 10^{7}$ cells $/ \mathrm{ml}$ in RPMI$10 \%$, and then incubated for $30 \mathrm{~min}$ at $4^{\circ} \mathrm{C}$ with OKT3 (anti-CD3; Ortho Diagnostic Systems, Raritan, NJ) and B4 (anti-CD19; Coulter Immunology, Hialeah, FL) monoclonal antibodies ( $50 \mu \mathrm{g} / \mathrm{ml}$ each). The cells were then washed three times with cold RPMI-10\% and incubated for $30 \mathrm{~min}$ at $4^{\circ} \mathrm{C}$ with goat anti-mouse IgG-coated magnetic particles (three particles per target cell; Dynabeads M-450; Dynal, Inc., Great Neck, NY), while being gently rotated every $5 \mathrm{~min}$. Next, the rosetted cells and beads were suspended in $5 \mathrm{ml}$ of RPMI-10\% and were attached to a samarium cobalt magnet (MPC-6). Nonrosetting cells were removed by pipetting, and the rosetted cells were washed seven times. The beads were subsequently detached by incubation of the cells at $5 \times 10^{5} / \mathrm{ml}$ in RPMI- $10 \%$ for $16-20 \mathrm{~h}$ at $37^{\circ} \mathrm{C}$. After incubation, most of the beads became detached and could be removed by magnetic attraction $(\times 5)$. The cells were then washed in RPMI$10 \%$ and stained directly for flow cytometric analysis (18). As detected by flow cytometry, the phenotypes of the purified $\mathrm{T}$ and $\mathrm{B}$ cells were $\mathrm{CD}^{+}(>95 \%)$ and $\mathrm{CD}^{+} 0^{+}(>90 \%)$, respectively.

Positive selection of $\mathrm{CD} 34^{+}$cells. Bone marrow was obtained by iliac crest aspiration from the five healthy volunteers and two leukemia patients in remission after they gave their informed consent. Mononuclear cells were isolated by Ficoll Conray gradient centrifugation, washed in RPMI-10\%, and then rosetted using Dynabeads M450 coated with an anti-CD34 monoclonal antibody (BI-3C5; Biosys, France). Rosetting was done for $45 \mathrm{~min}$ at $4^{\circ} \mathrm{C}$ with gentle tilting rotation, and a concentration of $1-2 \times 10^{8}$ bone marrow mononuclear cells per milliliter (1:1 bead to cell ratio) was found to be optimal. The rosetted cells and beads were then suspended in $5 \mathrm{ml}$ of RPMI-10\% and attracted to a magnetic particle concentrator (Dynal, Inc.). Nonrosetting cells (CD34 ${ }^{-}$ cells) were removed by pipetting and the rosetted cells were washed seven times. Beads were nonenzymatically detached from the positivelyselected cells by incubation for $60 \mathrm{~min}$ at room temperature with antiFab antiserum (DETACHaBEAD; Dynal, Inc.) in a final volume of 0.3 $\mathrm{ml}$ on a tilt rotator. After incubation, $1 \mathrm{ml}$ of RPMI-10\% was added, the beads were removed by magnetic attraction $(\times 3)$, and the isolated cells were suspended in RPMI-10\%. These cells were shown to be almost $60 \% \mathrm{CD}^{2} 4^{+}$by flow cytometric analysis.

DNA isolation and Southern blot analysis. High molecular weight DNA was extracted from PBMC and the above-mentioned five cell fractions using proteinase $\mathrm{K}$ digestion followed by phenol/chloroform extraction (19). We used the placenta as a source of control DNA for assessing the effect of cellular aging, instead of using embryonal cells (12). $5 \mu \mathrm{g}$ of genomic DNA was digested with restriction endonuclease Hinf I (Takara Shuzou Co., Kyoto, Japan), according to the supplier's recommendations. The resulting fragments were fractionated by electrophoresis on $0.8 \%$ agarose gel and transferred to nylon membranes ( $\mathrm{Hy}-$ bond N; Amersham Japan, Tokyo, Japan) according to the method described by Southern (20), after which they were hybridized with a ${ }^{32} \mathrm{P}$-labeled probe. The membranes were prehybridized for $16-24 \mathrm{~h}$ at $65^{\circ} \mathrm{C}$ in a solution containing $5 \times \mathrm{SSC}, 4 \times$ Denhardt's solution, $0.5 \%$ SDS, and $100 \mu \mathrm{g} / \mathrm{ml}$ denatured salmon sperm DNA. The oligonucleotide probe was hybridized for $16-24 \mathrm{~h}$ at $50^{\circ} \mathrm{C}$ in $5 \times \mathrm{SSC}$ and then washed at $50-60^{\circ} \mathrm{C}$ with $4 \times \mathrm{SSC}$. The hybridization solution for the Alu (BLUR-8) and alphoid sequences (pSP3) contained 10\% dextran sulfate in addition to the prehybridization mixture. Hybridization was allowed to proceed for $24 \mathrm{~h}$ at $65^{\circ} \mathrm{C}$, after which the filters were washed for 30 min at the same temperature in $0.5 \times$ SSC and $0.5 \%$ SDS. Prehybridization and hybridization for the triplet repeat probe $(\mathrm{CAC})_{5}$ were done in $5 \times \operatorname{SSPE}\left(0.9 \mathrm{M} \mathrm{NaCl}, 50 \mathrm{mM} \mathrm{NaPO}_{4}, \mathrm{PH} 7.7,5 \mathrm{mM}\right.$ EDTA $), 5 \times$
Denhardt's solution, $0.1 \%$ SDS, and $100 \mu \mathrm{g} / \mathrm{ml}$ denatured salmon sperm DNA for $16-24 \mathrm{~h}$ at $45^{\circ} \mathrm{C}$, after which the filters were washed for 30 $\min$ in $0.5 \times$ SSC and $0.5 \%$ SDS at room temperature. The membranes were then exposed to x-ray film (Eastman Kodak Co., Rochester, NY) for an appropriate length of time at $-80^{\circ} \mathrm{C}$ with an intensifying screen. The lengths of telomeric repeats were measured with a computer-controlled laser beam densitometer (ACD-25DX; Atto, Tokyo, Japan).

DNA clones. The following DNA probes were used. Deoxynucleotide polymers (TTAGGG) $)_{7}$, usually $2 \mathrm{ng}$ of a $42 \mathrm{mer}$, were end-labeled in the presence of ${ }^{32} \mathrm{P}$-dCTP (Amersham), using terminal deoxynucleotidyl transferase in the recommended buffer (GIBCO BRL, Gaithersburg, MD). Cloned pSP3 DNA (consisting of 849 bp alphoid sequences), which recognizes the tandemly repeated DNA sequences at the centromeric region of human chromosomes (21), and the clone BLUR-8 (22), a repetitive DNA of the Alu family which is interspersed throughout human chromosomes, were labeled with ${ }^{32} \mathrm{P}-\mathrm{dCTP}$ using a random primer labeling kit (Amersham). In some cases, the blots were rehybridized with the ${ }^{32} \mathrm{P}$-end-labeled microsatellite probe $5^{\prime}-(\mathrm{CAC})_{5}-3^{\prime}$ to confirm that both normal and leukemic DNA samples were from the same patient and that equal amounts of DNA had been loaded for each pair of samples (12).

\section{Results}

Clinical and laboratory findings. The clinical and hematologic findings of the 12 patients at the time of diagnosis are summarized in Table I. They consisted of six men and six women aged from 30 to 77 years (average: $55 \mathrm{yr}$ ). According to the FrenchAmerican-British classification (23), there were two patients with M1, two with M2, two with M4, one with M5, and five with L2. Leukocytosis was present in all 12 patients, with the white blood cell count ranging from 15.2 to $140.0 \times 10^{9} /$ liter (average: $69.5 \times 10^{9} /$ liter). Leukemic cells accounted for 66 to $99 \%$ of the circulating white blood cells (average: $89 \%$ ). Cytogenetic analysis was performed on bone marrow aspirates at diagnosis in 10 of the 12 patients and disclosed a diploid karyotype in 8 of them, including 4 normal karyotypes, 1 hypodiploid karyotype, and 1 hyperdiploid karyotype.

Telomere reduction in leukemic cells. We studied telomeric DNA in blast cells obtained from seven patients with acute myeloid leukemia and in their PBMC obtained during remission. As shown in Fig. 1, the telomeric DNA of the leukemic cells was actually smaller than that of the mononuclear cells obtained from the same patients during remission. When the filters that had been hybridized to (TTAGGG) 7 were stripped and rehybridized to pSP3 or BLUR-8, no marked differences were observed in the sizes of the repetitive DNA sequences found in the leukemic cells and PBMC (Fig. 2), indicating that the DNA changes were specific to the telomeric regions. Loss of telomeric DNA did not occur as a result of general degradation or the loss of repetitive DNA during the preparation of DNA from old cells, as other repetitive, nontelomeric sequence elements analyzed in the same filters were not altered either in size or amount (Fig. 3). We then examined the telomeric DNA in blast cells from five patients with acute lymphoblastic leukemia and in their PBMC obtained during remission. As shown in Fig. 4, the telomeric DNA of the leukemic cells was also smaller than that of the mononuclear cells obtained from the same patients during remission. When the same filters were rehybridized to the Alu or alphoid sequences, they did not show any differences relative to the PBMC obtained in remission (data not shown). 


\begin{tabular}{|c|c|c|c|c|c|c|c|c|}
\hline \multirow[b]{2}{*}{ Case } & \multirow[b]{2}{*}{ Age } & \multirow[b]{2}{*}{ Sex } & \multirow[b]{2}{*}{ FAB } & \multirow{2}{*}{$\begin{array}{c}\text { WBC } \\
\times 10^{9} / \text { liter }\end{array}$} & \multirow[b]{2}{*}{ Blasts } & \multicolumn{2}{|c|}{ No. of mitoses } & \multirow[b]{2}{*}{ Cytogenetics } \\
\hline & & & & & & Abnormal & Normal & \\
\hline & & & & & $\%$ & & & \\
\hline 1 & 75 & $\mathrm{~F}$ & M5a & 96 & 95 & 33 & 0 & $46, \mathrm{XX}, \mathrm{t}(9 ; 11)(\mathrm{p} 22 ; \mathrm{q} 23)$ \\
\hline 2 & 40 & $\mathbf{M}$ & M1 & 110 & 96 & 0 & 30 & $46, X Y$ \\
\hline 3 & 40 & $\mathbf{M}$ & M4e & 140 & 98 & 20 & 10 & $46, X Y, \operatorname{inv}(16)(p 13 q 22)$ \\
\hline 4 & 65 & $\mathbf{F}$ & M1 & 110 & 96 & 0 & 30 & $46, \mathrm{XX}$ \\
\hline 5 & 72 & $\mathbf{M}$ & M2 & 28.6 & 79 & 0 & 30 & $46, X Y$ \\
\hline 6 & 43 & $\mathbf{M}$ & M2 & 38.3 & 78 & 29 & 1 & $45, \mathrm{X},-\mathrm{Y}, \mathrm{t}(8 ; 21)(\mathrm{q} 22 ; \mathrm{q} 22)$ \\
\hline 7 & 67 & $\mathrm{~F}$ & M4 & 36.3 & 66 & 0 & 30 & $46, X X$ \\
\hline 8 & 45 & $\mathrm{~F}$ & L2 & 15.2 & 90 & ND & ND & ND \\
\hline 9 & 30 & $\mathbf{M}$ & L2 & 69.0 & 93 & ND & ND & ND \\
\hline 10 & 75 & $\mathbf{M}$ & $\mathrm{L} 2$ & 27.8 & 86 & 30 & 0 & $46, X Y, t(9 ; 22)(q 34 ; q 11)$ \\
\hline 11 & 77 & $\mathrm{~F}$ & L2 & 140 & 97 & 30 & 0 & $47, X X,-9,-22,+\operatorname{del}(9 q+)(p 13 ?),+22 q-,+22 q-$ \\
\hline 12 & 34 & $\mathrm{~F}$ & $\mathrm{~L} 2$ & 22.2 & 99 & 32 & 3 & $46, \mathrm{XX}, \mathrm{t}(4 ; 11)(\mathrm{q} 21 ; \mathrm{q} 23)$ \\
\hline
\end{tabular}

ND, not done; WBC, white blood cells.

Most studies of acute leukemia have supported the assumption that leukemic blasts represent clonal expansion and arrest of maturation at a stage of normal cell differentiation that has either lymphoid or myeloid characteristics. To determine whether the telomere reduction in leukemic blasts was simply due to cellular immaturity, we compared the telomeric DNA of leukemic cells with that of $\mathrm{CD} 34^{+}$cells obtained from the same patient after long-term remission had been achieved. CD34 ${ }^{+}$ cells contain the precursors of colony-forming cells that can be detected in long-term bone marrow culture (24) and coexpress antigens that are present on immature $\mathrm{T}$ and $\mathrm{B}$ lymphocytes (25-27). As shown in Fig. 5, the telomere length of CD34 ${ }^{+}$

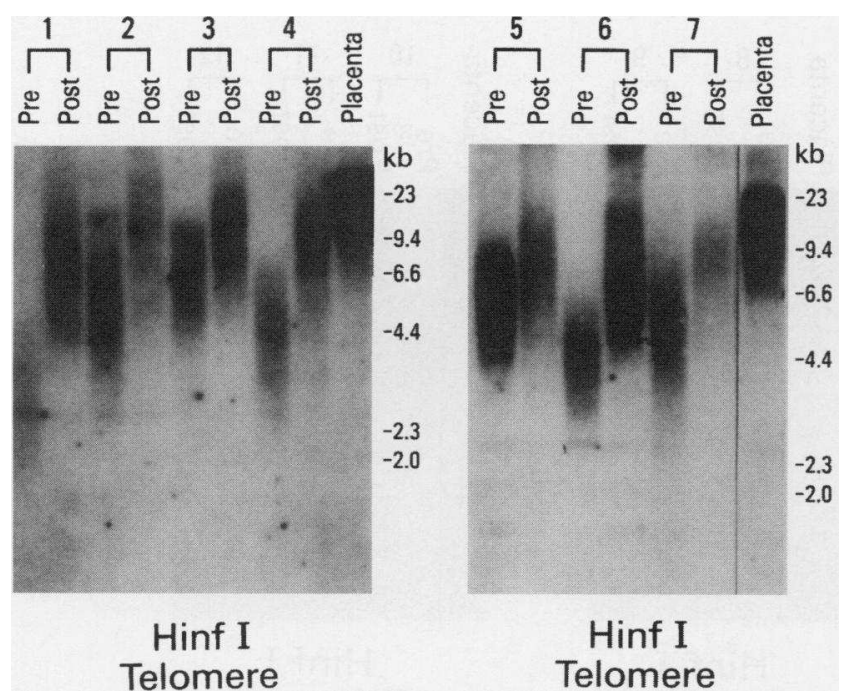

Figure 1. Southern blot analysis of the seven acute myeloid leukemia patients at diagnosis and in remission. DNA from the patients (cases 1-7) and from a human placenta was digested with Hinf I and hybridized with the DNA probe to the telomere sequence. Pre and Post refer to samples obtained before and after hematological remission, respectively. cells was $8.4 \mathrm{~kb}$ in patient 2 and $9.0 \mathrm{~kb}$ in patient 4 and there was a significant difference in the telomeric DNA length between the leukemic and $\mathrm{CD} 34^{+}$cell populations, indicating that shortened telomere repeat arrays were specific to leukemic cells. DNA loading and integrity were checked again by rehybridizing the same filter to a multilocus oligonucleotide probe $(\mathrm{CAC})_{5}$, and no differences were found in each pair of samples.

To assess the extent of reduction of the telomeric DNA repeats in leukemic cells, we performed densitometric scanning of the autoradiographs. The lengths of the telomeric DNA signal peaks are shown in Fig. 6. There was some variation in the lengths of the telomeric DNA repeats from the leukemic cells of the 12 patients, with a range from 2.7 to $6.4 \mathrm{~kb}$. In all the leukemic cells, there was shortening of the telomeric DNA at the time of diagnosis, and the reduction ranged from 32 to $63 \%$ relative to the telomere length in PBMC obtained from the same patients at remission. The average telomere length of the leukemic cells was $4.8 \mathrm{~kb}$ before treatment and $8.5 \mathrm{~kb}$ after treatment in the patients with myeloid leukemia, while it was $4.7 \mathrm{~kb}$ before treatment and $7.9 \mathrm{~kb}$ after treatment in those with lymphoid leukemia.

Telomeric DNA sizes in different cell populations from normal blood cells. Ficoll-isolated mononuclear cells contain several different types of cells. To determine whether differences in PBMC composition could influence the telomeric DNA size and consequently cause some potential bias to our findings regarding the degree of telomere reduction, we compared telomeric DNA in the T cells, B cells, polymorphonuclear leukocytes, monocytes, and CD34+ cells from five normal healthy donors. As shown in Fig. 7, the telomeric DNA of each of these cell fractions in the donors in their twenties, thirties, forties, fifties, and sixties was respectively $9.2,9.2,9.2,8.6,9.0 \mathrm{~kb}$; 8.9, 9.1, 8.3, 8.3, 8.0 kb; 8.4, 8.6, 8.0, 8.3, 8.5 kb; 9.0, 9.2, 9.0, 9.2, $9.0 \mathrm{~kb}$; and $8.4,8.8,8.2,8.2,8.4 \mathrm{~kb}$. Although the DNA in these cell populations was smaller than the placental DNA used as a control, there were no marked differences in the amounts and lengths of the telomeric DNA in the various cell populations or with respect to aging among the five individuals. 

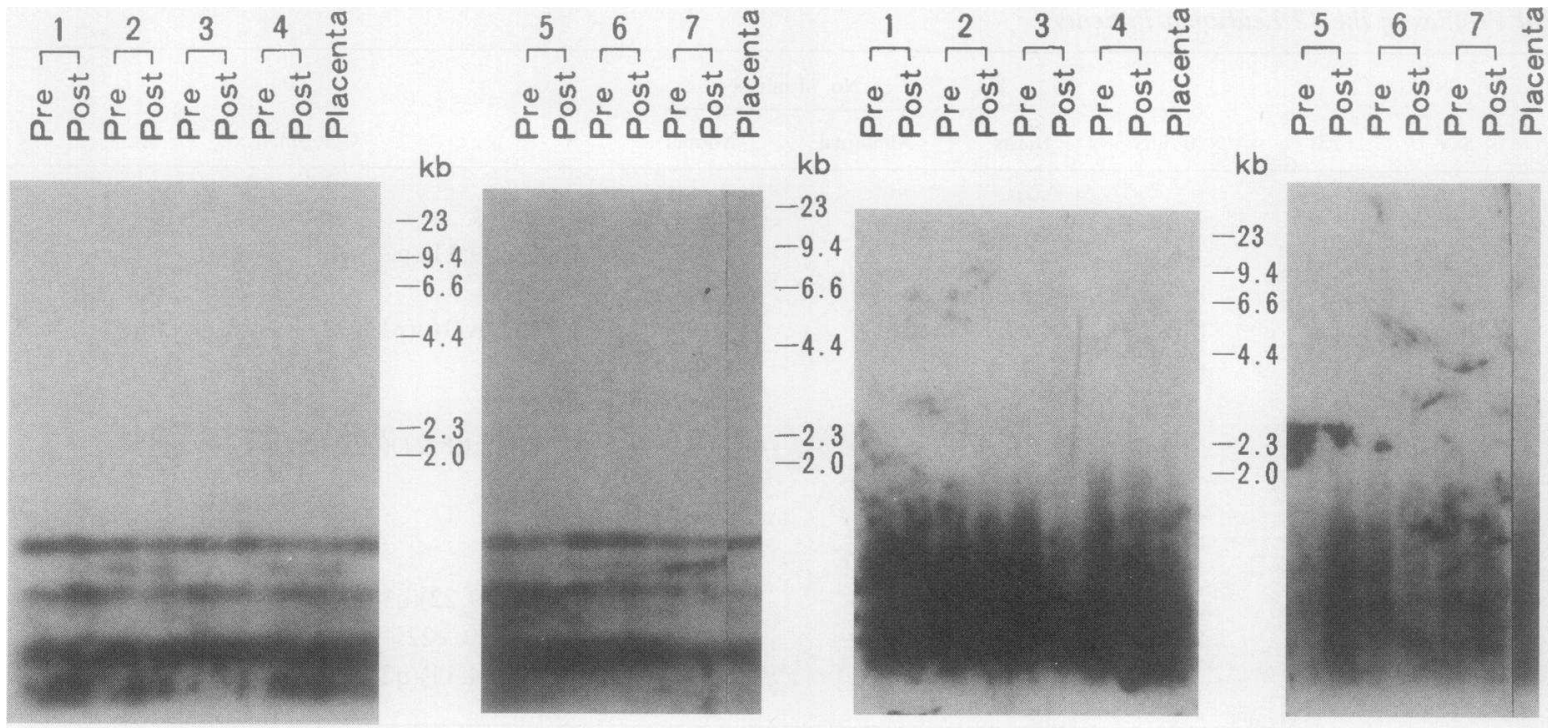

\section{Hinf I \\ Alphoid}

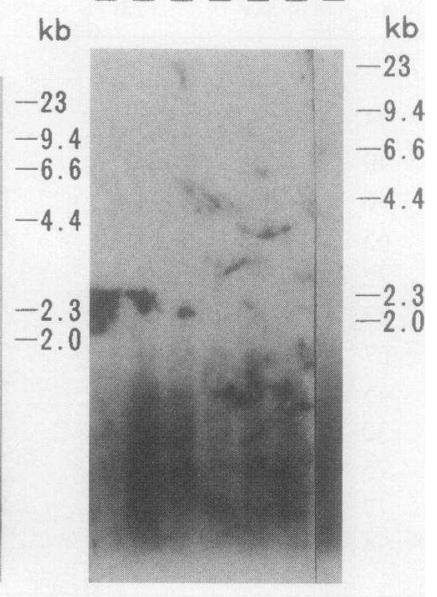

Hinf I

Alu

Figure 2. Southern blot analysis of the seven acute myeloid leukemia patients at diagnosis and in remission. The nylon filters used for the experiment described in Fig. 1 were subsequently boiled for $5 \mathrm{~min}$ in $1 \%$ SDS and rehybridized with the Alu or alphoid DNA probes.

It was also shown that differentiation from $\mathrm{CD} 34^{+}$cells, which exhibit hematopoietic stem cell characteristics, to terminally differentiated polymorphonuclear cells did not cause any significant change in the length of telomeric DNA.

\section{Discussion}

Telomere sequences contain no protein code, but they have an important role in maintaining chromosomal stability and activity
$(1,4)$. At the chromosomal level, translocations arising through tandem fusions of telomeres were first observed in leukemic B cells (9). Subsequently, telomeric fusions have been reported in a pre-T cell acute lymphoblastic leukemia (10) and in some solid tumors, including histiocytoma (28), cardiac myxoma (29), and renal tumors (30). All these studies have suggested that abnormalities of the ends of chromosomes are present in some tumors. However, shortening and a reduction in the num-

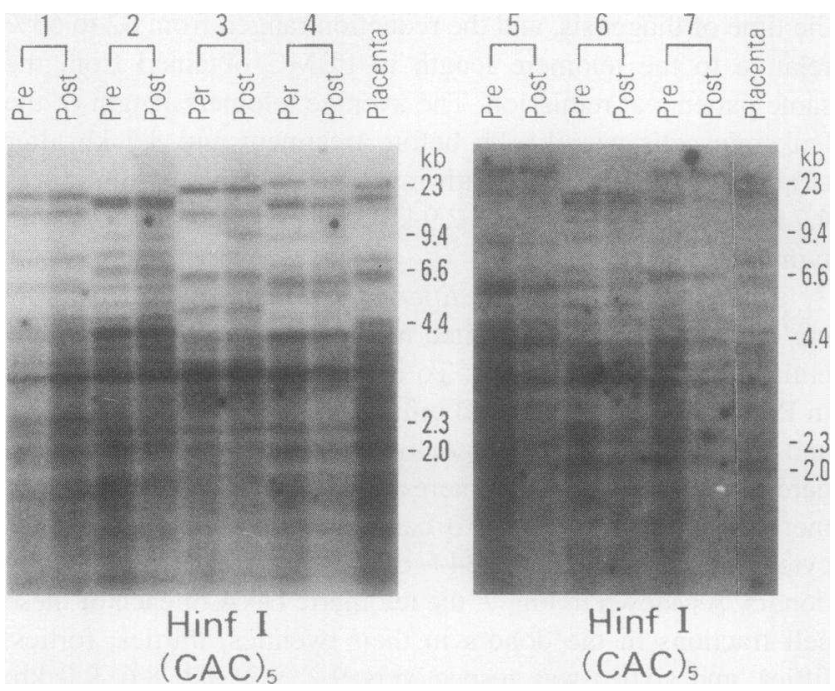

Figure 3. Southern blot analysis of the seven acute myeloid leukemia patients at diagnosis and in remission. The filters were first hybridized for the experiments described in Figs. 1 and 2, after which they were stripped and rehybridized with a multilocus oligonucleotide probe $(\mathrm{CAC})_{5}$ in order to confirm the initial quality and quantity of the genomic DNA.
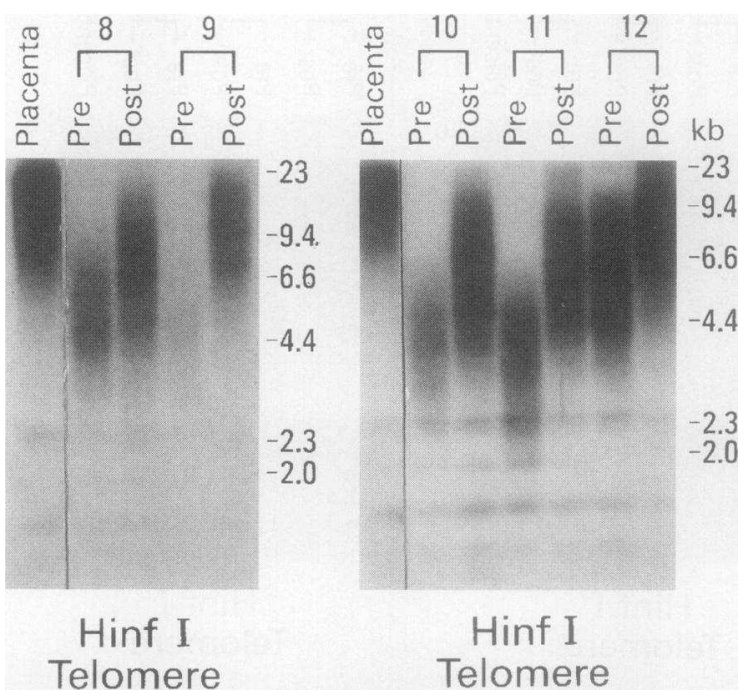

Figure 4. Southern blot analysis of the five acute lymphoblastic leukemia patients at diagnosis and in remission. DNA from patients 8-12 and from a human placenta was digested with Hinf I and hybridized with the DNA probe to the telomere sequence. Pre and Post refer to samples obtained before and after hematological remission, respectively. 

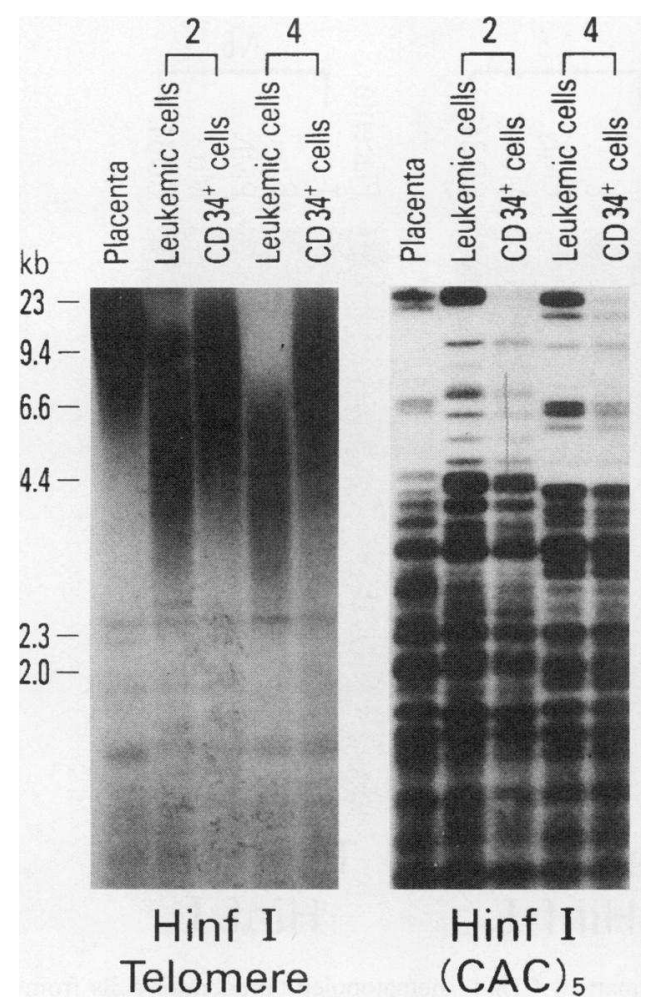

Figure 5. Southern blot analysis of two acute myeloid leukemia patients at diagnosis and in long-term remission. DNA from leukemic cells (cases 2 and 4 ), $\mathrm{CD} 34^{+}$cells obtained from the same patients in longterm remission and from a human placenta was digested with Hinf I and hybridized with the DNA probe to the telomere sequence, after which the filter was rehybridized with the minisatellite probe $(\mathrm{CAC})_{5}$.

ber of telomeric DNA sequences have only been reported in some solid tumors up to the present $(11-14)$.

In this study, we demonstrated that human telomeric DNA, which is located at the ends of chromosomes, was partially lost in all 12 leukemia patients examined. The changes of telomeric DNA were present even in leukemic cells with a normal karyotype, and the degree of DNA reduction did not correlate with the extent of the chromosomal abnormalities. The average telomere length in the leukemic cells was $4.7 \mathrm{~kb}$ before treatment, and it recovered to $8.2 \mathrm{~kb}$ after treatment, which was similar to the length we determined previously in the PBMC of healthy individuals (15).

Leukemic cells are immature and are characterized by a block in the normal sequence of differentiation (31). CD $34^{+}$ cells constitute a minor population $(0.1-0.5 \%)$ of the cells in human bone marrow and peripheral blood, and have the properties of primitive stem cells (32). Although we could assess only two patients, we found that the degree of telomere reduction in the leukemic cells was always greater than that in the CD34 ${ }^{+}$ cells obtained from the same patient in remission, suggesting that this reduction was not merely the result of immaturity.

These results suggest that telomeres are unstable and that they lose sequences during the course of tumorigenesis in leukemia. On the other hand, the Alu and alphoid sequences, which are thought to have important biological functions with regard to gene regulation and cell division, were not affected, sug-

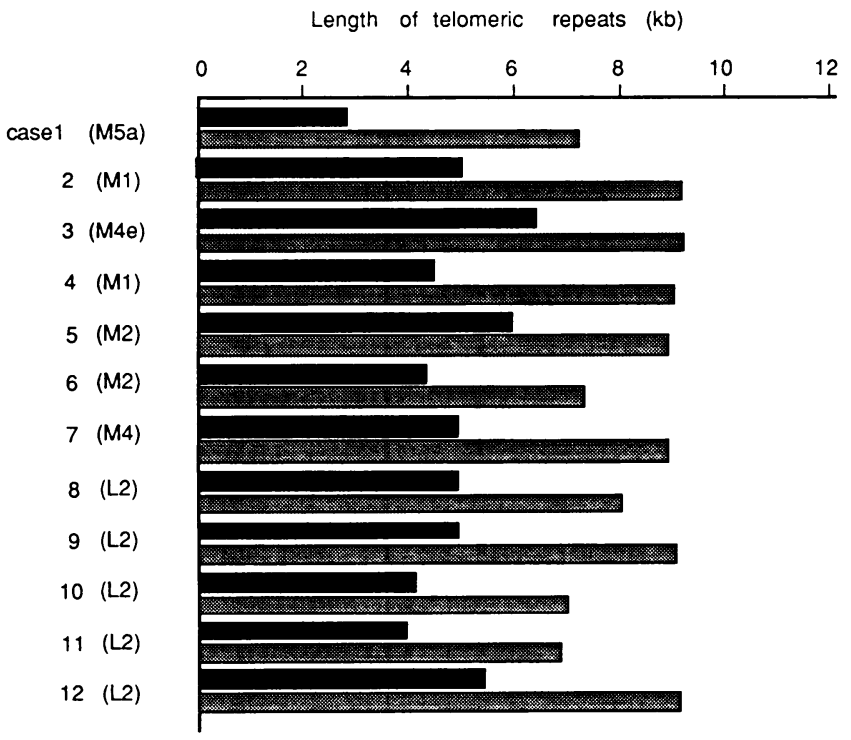

Figure 6. Telomere lengths determined in the 12 leukemia patients at diagnosis and in remission. The autoradiographs shown in Figs. 1 and 4 were analyzed with an automatic autoradiographic scanner to determine the peak fractions of the telomeric repeats in PBMC. Solid and shaded bars indicate samples obtained at diagnosis and during hematological remission, respectively.

gesting that telomere shortening may not have a crucial effect on cell growth.

We also analyzed the genomic DNA from five healthy donors, who ranged in age from their twenties to sixties. We found that the telomeric DNA of T lymphocytes, B lymphocytes, polymorphonuclear leukocytes, monocytes, and $\mathrm{CD}_{3} 4^{+}$cells was smaller than the placental DNA used as a control, and that the size did not vary significantly from one cell population to another. This suggested that the normal leukocytes which may have contaminated our isolated leukemic cells had no detectable influence on the telomere shortening that we found in this study.

CD $34^{+}$cells contain myeloid precursors $(24,32)$, and the telomeric DNA of this immature cell subset was found to be almost the same length as that of terminally differentiated polymorphonuclear leukocytes which have no proliferative activity. Previous analyses of telomere length have shown that the telomere is shorter in somatic cells than in germ line cells and that the length decreases with cellular aging $(12,33)$. However, the effects of cellular aging on peripheral blood cells, which have a limited life span and are constantly renewed, may be very different from those noted in other tissues.

What is the mechanism underlying this telomere reduction? It could reflect the number of cell divisions required to produce the leukemic cells in the absence of telomerase, which can add TTAGGG repeats to G-rich primers (34). In somatic cells, telomere loss may be due to incomplete DNA replication in the absence of telomerase, and this provides a mitotic clock that ultimately causes cell cycle exit and cell death $(35,36)$. It has been suggested that telomerase is reactivated in somatic cells that are immortalized during tumorigenesis (37). Thus, telomerase apparently balances telomere loss by the de novo synthesis of telomeric DNA in immortal cells. In leukemic cells, we found that the average telomere length was shorter than that 

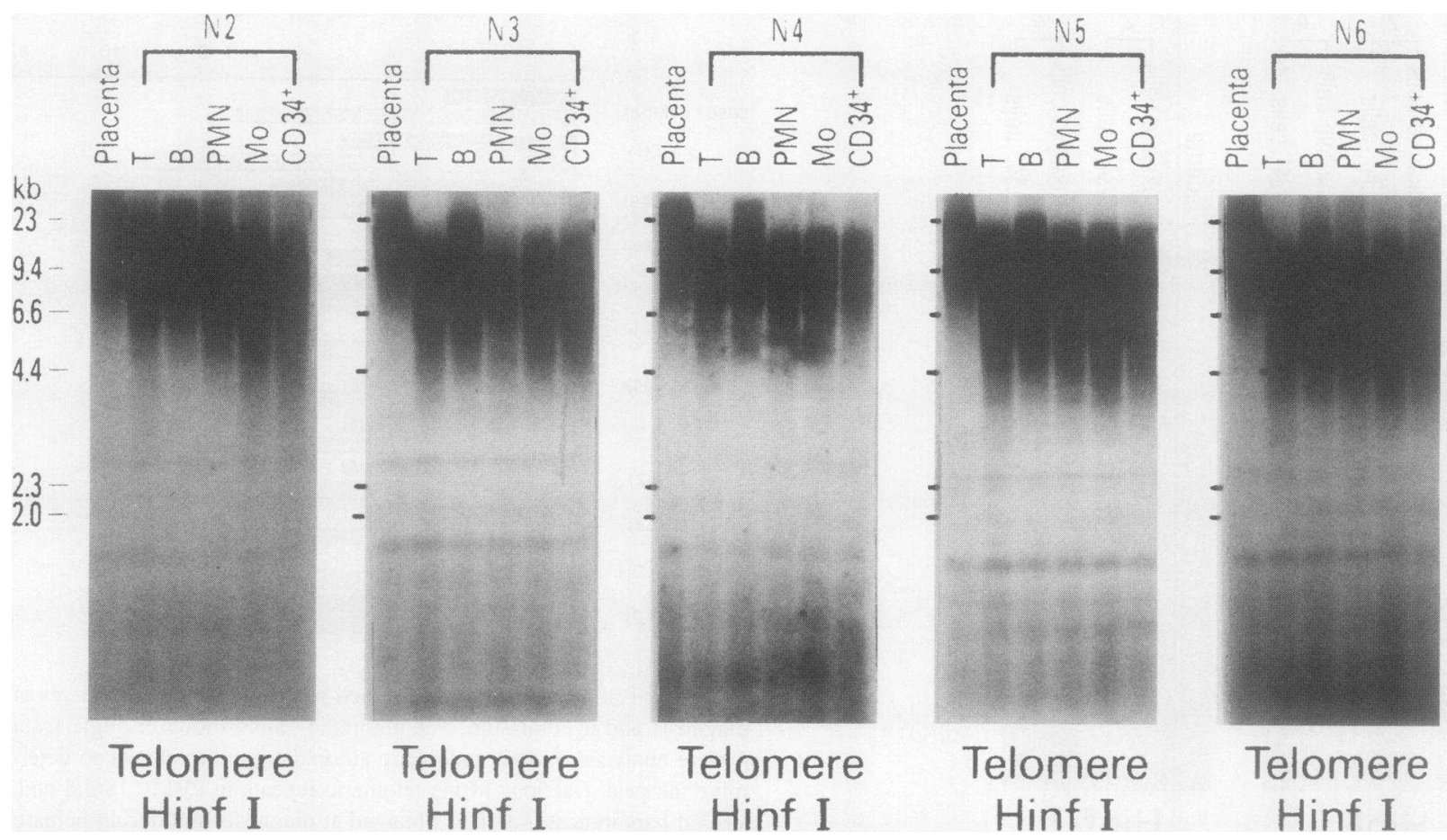

Figure 7. Southern blot analysis of four different peripheral blood cell fractions and of bone marrow CD $34^{+}$hematopoietic progenitor cells from the same five healthy donors. DNA from T lymphocytes, B lymphocytes, polymorphonuclear leukocytes, monocytes, CD $34^{+}$cells and human placenta was digested with Hinf I and hybridized with the DNA probe to the telomere sequence. $N 2-N 6$ designate normal volunteers aged from their twenties to sixties, respectively.

detected in the PBMC obtained during remission. It is thus conceivable that telomerase becomes reactivated as a late event in cell transformation, and that cells can remain viable with short telomeres provided they are stably maintained by telomerase. In addition, cells with shorter telomeres may possibly have a growth advantage over cells with longer telomeres (38).

Telomere loss could be a consequence of tumorigenesis, or alternatively could be involved in the development of malignancy. Assuming that (TTAGGG) $n$ is essential for telomere function (39), the partial loss of these sequences would eventually destabilize the ends of chromosomes. Chromosomes lacking terminal repeats may become less stable and more prone to the fusion-bridge-breakage cycle described by McClintock (3), which leads to the formation of daughter cells containing partly deleted and partly duplicated chromosomes. Deletions or losses by these routes could also play a part in generating the loss of alleles of restriction fragment length polymorphisms, which is thought to reflect the requirement for mutations in tumor suppressor genes to be homozygous before the evolution of malignancy can occur $(40,41)$. However, the role played by telomere reduction in the process of tumorigenesis remains controversial, and this issue will only be resolved by studying a larger sample of a variety of human leukemic cells. Thus, further research is necessary to determine the mechanism underlying telomere shortening in human hematopoietic cells and its relevance to the development and progression of leukemia.

\section{References}

1. Blackburn, E. H. 1991. Structure and function of telomeres. Nature (Lond.). 350:569-573.
2. Muller, H. J., and I. H. Herskowitz. 1954. Concerning the healing of chromosome ends produced by breakage in Drosophila melanogaster. Am. Nat. 88:177-208.

3. McClintock, B. 1941. The stability of broken ends of chromosomes in Zea mays. Genetics. 26:234-282.

4. Moyzis, R. K. 1991. The human telomere. Sci. Am. 265:34-41.

5. Agard, D. A., and J. W. Sedat. 1983. Three-dimensional architecture of a polytene nucleus. Nature (Lond.). 302:676-681.

6. Watson, J. D. 1972. Origin of concatemeric T7 DNA. Nature (New Biol.). 239:197-201.

7. Yu, G. L., J. D. Bradley, L. D. Attardi, and E. H. Blackburn. 1990. In vivo alteration of telomeric sequences and senescence caused by mutated Tetrahymena telomerase RNAs. Nature (Lond.). 344:126-132.

8. Lustig, A. J., S. Kurts, and D. Shore. 1990. Involvement of the silencer and UAS binding protein RAP1 in regulation of telomere length. Science (Wash. DC). 250:549-553.

9. Fitzgerald, P. H., and C. H. Marris. 1984. Telomeric association of chromosomes in B-cell lymphoid leukemia. Hum. Genet. 67:385-390.

10. Morgan, R., V. Jarzabek, J. P. Jaffe, B. K. Hecht, F. Hecht, and A. A Sandberg. 1986. Telomeric fusion in pre-T-cell lymphoblastic leukemia. Hum. Genet. 73:260-263.

11. de Lange, T., L. Shiue, R. M. Myers, D. R. Cox, S. L. Naylor, A. M. Killery, and H. E. Varmus. 1990. Structure and variability of human chromosome ends. Mol. Cell. Biol. 10:518-527.

12. Hastie, N. D., M. Dempster, M. G. Dunlop, A. M. Thompson, D. K. Green, and R. C. Allshire. 1990. Telomere reduction in human colorectal carcinoma and with ageing. Nature (Lond.). 346:866-868.

13. Smith, J. K., and G. Yeh. 1992. Telomere reduction in endometrial adenocarcinoma. Am. J. Obstet. Gynecol. 167:1883-1887.

14. Counter, C. M., H. W. Hirte, S. Bacchetti, and C. B. Harley. 1994 Telomerase activity in human ovarian carcinoma. Proc. Natl. Acad. Sci. USA. 91:2900-2904.

15. Yamada, O., K. Oshimi, and H. Mizoguchi. 1993. Telomere reduction in hematologic cells. Int. J. Hematol. 57:181-186.

16. Ferrante, A., and Y. H. Thong. 1980. Optimal conditions for simultaneous purification of mononuclear and polymorphonuclear leukocytes from human blood by the Hypaque-Ficoll method. J. Immunol. Methods. 36:109-117.

17. Li, C. Y., K. W. Lam, and L. T. Yam. 1973. Esterases in human leukocytes. J. Histochem. Cytochem. 21:1-12. 
18. Oshimi, K., Y. Oshimi, O. Yamada, M. Wada, T. Hara, and H. Mizoguchi. 1990. Cytotoxic $\mathrm{T}$ lymphocyte triggering via CD16 is regulated by CD3 and CD8 antigens. J. Immunol. 144:3312-3317.

19. Maniatis, T., E. F. Fritsch, and J. Sambrook. 1982. Molecular Cloning: A Laboratory Manual (1st ed.). Cold Spring Harbor Laboratory Press, Cold Spring Harbor, NY. 545 pp.

20. Southern, E. M. 1975. Detection of specific sequences among DNA fragments separated by electrophoresis. J. Mol. Biol. 98:503-517.

21. Kiyama, R., H. Matsui, and M. Oishi. 1986. A repetitive DNA family (Sau 3A family) in human chromosomes: Extrachromosomal DNA and DNA polymorphism. Proc. Natl. Acad. Sci. USA. 83:4665-4669.

22. Houck, C. H., F. P. Rinehart, and C. W. Schmid. 1979. A ubiquitous family of repeated DNA sequences in the human genome. J. Mol. Biol. 132:289306.

23. Bennett, J. M., D. Catovsky, M. T. Daniel, G. Flandrin, D. A. G. Galton, H. R. Gralnick, and C. Sultan. 1985. Proposed revised criteria for the classification of acute myeloid leukemia. Ann. Intern. Med. 103:626-636.

24. Andrews, R. G., J. W. Singer, and I. D. Bernstein. 1986. Monoclonal antibody 12-8 recognizes a 115-kd molecule present on both unipotent and multipotent hematopoietic colony-forming cells and their precursors. Blood. 67:842-845.

25. Ryan, D. H., C. W. Chapple, S. A. Kossover, A. A. Sandberg, and H. J. Cohen. 1987. Phenotypic similarities and differences between CALLA-positive acute lymphoblastic leukemia cells and normal marrow CALLA-positive B cell precursors. Blood. 70:814-821.

26. Loken, M. R., V. O. Shah, K. L. Dattilio, and C. I. Civin. 1987. Flow cytometric analysis of human bone marrow. II. Normal B lymphocyte development. Blood. 70:1316-1324.

27. Kutzberg, J., S. M. Denning, L. M. Nycum, K. H. Singer, and B. F. Haynes. 1989. Immature human thymocytes can be driven to differentiate into nonlymphoid lineages by cytokines from thymic epithelial cells. Proc. Natl. Acad. Sci. USA. 86:7575-7579.

28. Mandahl, N., S. Heim, V. Kristoffersson, F. Mitelman, B. Rööser, A Rydholm, and H. Willén. 1985. Telomeric association in a malignant fibrous histiocytoma. Hum. Genet. 71:321-324.

29. Dewald, G. W., R. S. Dahl, J. L. Spurbeck, J. A. Carney, and H. Gordon.
1987. Chromosomally abnormal clones and nonrandom telomeric translocations in cardiac myxomas. Mayo Clin. Proc. 62:558-567.

30. Kovacs, G., B. R. Müller, and S. Szücs. 1987. Telomeric association in two human renal tumors. Cancer Genet. Cytogenet. 28:363-365.

31. Nichols, J., and S. D. Nimer. 1992. Transcription factors, translocations, and leukemia. Blood. 80:2953-2963.

32. Andrews, R. G., E. M. Bryant, S. H. Bartelmez, D. Y. Muirhead, G. H. Knitter, W. Bensinger. 1992. CD34 ${ }^{+}$marrow cells, devoid of T and B lymphocytes, reconstitute stable lymphopoiesis and myelopoiesis in lethally irradiated allogeneic baboons. Blood. 80:1693-1701.

33. Allsopp, R. C., H. Vaziri, C. Patterson, S. Goldstein, E. V. Younglai, A. B. Futcher, C. W. Greider, and C. B. Harley. 1992. Telomere length predicts replicative capacity of human fibroblasts. Proc. Natl. Acad. Sci. USA. 89:1011310119.

34 Harrington, L. A., and C. W. Greider. 1991. Telomerase primer specificity and chromosome healing. Nature (Lond.). 353:451-454.

35. Levy, M. Z., R. C. Allsopp, A. B. Futcher, C. W. Greider, and C. B. Harley. 1992. Telomere end-replication problem and cell aging. J. Mol. Biol. 225:951-960.

36. Christopher, M. C., A. A. Avilion, C. E. Lefeuvre, N. G. Stewart, C. W. Greider, C. B. Harley, and S. Bacchetti. 1992. Telomere shortening associated with chromosome instability is arrested in immortal cells which express telomerase activity. EMBO. (Eur. Mol. Biol. Organ.) J. 11:1921-1929.

37. Harley, C. B. 1991. Telomere loss:mitotic clock or genetic time bomb ? Mutat. Res. 256:271-282.

38. Larson, D. D., E. A. Spangler, and E. H. Blackburn. 1987. Dynamics of telomere length variation in Tetrahymena thermophila. Cell. 50:477-483.

39. Moyzis, R. K., J. M. Buckingham, L. S. Cram, M. Dani, L. L. Deaven, M. D. Jones, J. Meyne, R. L. Ratliff, and J. R. Wu. 1988. A highly conserved repetitive DNA sequence, (TTAGGG) $n$ mosomes. Proc. Natl. Acad. Sci. USA. 85:6622-6626.

40. Vogelstein, B., E. R. Fearon, S. R. Hamilton, S. E. Kern, A. C. Preisinger, M. Leppert, Y. Nakamura, R. White, A. M. M. Smits, and J. L. Bos. 1988. Genetic alterations during colorectal tumor development. N. Engl. J. Med. 319:525-532.

41. Vogelstein, B., E. R. Fearon, S. E. Kern, S. R. Hamilton, A. C. Preisinger, Y. Nakamura, and R. White. 1989. Allelotype of colorectal carcinomas. Science (Wash. DC). 244:207-211. 